PUBLIKAUMA: Jurnal Ilmu Administrasi Publik UMA, 9 (2) (2021): 9-18

DOI http://dx.doi.org/10.31289/publika.v9i2.5274

PUBLIKAUMA: Jurnal Ilmu Administrasi Publik

Available online http://ojs.uma.ac.id/index.php/publikauma

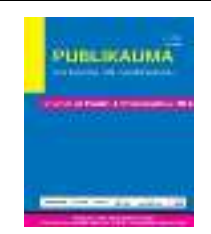

\title{
Pengelolaan Pasar Klewer Pasca Kebakaran Berbasis Collaborative Governance (Perspektif Civil Society)
}

\section{Collaborative Governance Based Post-Fire Pasar Klewer Management From Civil Society Perspective}

\author{
Yitno Puguh Martomo ${ }^{1}$, Khairul ${ }^{2}$ \\ ${ }^{1}$ Fakultas Ilmu Sosial dan Ilmu Politik, Universitas Surakarta \\ ${ }^{2}$ Sekolah Tinggi Ilmu Sosial dan Ilmu Politik, Padang
}

Disetujui: Oktober 2021; Direview: Oktober 2021;Diterima: Nopember 2021

\begin{abstract}
Abstrak
Kompleksitas yang muncul pasca kebakaran pasar Klewer diteliti melalui pengelolaan yang berbasis collaborative governance, dengan mensinergikan antara government, civil society, dan privat. Tujuan penelitian menganalisis pelaksanaan collaborative governance dari perspektif civil society. Penelitian ini menggunakan pendekatan kualitatif dengan metode fenomenologi untuk mengungkapkan realita dari sudut pandang orang yang mengalaminya secara langsung atau berkaitan dengan pengalamannya. Teknik pengumpulan data menggunakan Teknik wawancara, Teknik observasi, dan dokumentasi. Sedangkan analisis data menggunakan model inter aktif yang meliputi pengumpulan data, kondensasi data, sajian data, dan penarikan kesimpulan. Civil society sebagai perspektif dalam collaborative governance dari aspek ketahanan budaya berhasil mempertahankan nilai luhur budaya lokal warisan Keraton. Aspek Benefit menghasilkan semangat untuk bangkit dan menjadi motivasi dalam memenuhi tuntutan kebutuhan keluarga sekaligus sebagai simbol pengusaha local. Aspek partisipasi berhasil mempercepat kelancaran kegiatan atau operasional pasar. Simpulan penelitian ini adalah Collaborative Governance dari perspektif Civil Society menjadikan kolaborasi pengelolaan pasar klewer pasca kebakaran lebih efektif.
\end{abstract}

Kata Kunci: Collaborative Governance, Civil Society, Pasca Kebakaran

\section{Abstract}

The complexities that emerged after the Klewer market fire were investigated through collaborative governance-based management, by synergizing between government, civil society, and the private sector. The research objective is to analyze the implementation of collaborative governance from the perspective of civil society. This study uses a qualitative approach with phenomenological methods to reveal reality from the point of view of people who experience it directly or related to their experience. Data collection techniques using interview techniques, observation techniques, and documentation. Meanwhile, the data analysis used an interactive model which included data collection, data condensation, data presentation, and concluding. Civil society as a perspective in collaborative governance from the aspect of cultural resilience has succeeded in maintaining the noble values of the local culture inherited from the Palace. The Benefit aspect generates enthusiasm to rise and become motivation in meeting the demands of family needs as well as a symbol of local entrepreneurs. The participation aspect has succeeded in accelerating the steady running of market activities or operations. This research concludes that Collaborative Governance from the perspective of Civil Society makes collaboration in managing the post-fire Klewer market more effective.

Keywords: Collaborative Governance, Civil Society, Post Fire

How to Cite Martomo, Y.P. \& Khairul (2021). Pengelolaan Pasar Klewer Pasca Kebakaran Berbasis Collaborative Governance (Perspektif Civil Society). PUBLIKAUMA: Jurnal Ilmu Administrasi Publik UMA, Vol 9 (2): Vol.9 (2): 9 18

*Corresponding author:

ISSN 2549-1660 (Print)

E-mail: tomounsa@gmail.com

ISSN 2580-2011 (Online) 



\section{PENDAHULUAN}

Pasar tradisional tidak saja berfungsi sebagai pusat ekonomi kerakyatan, tapi juga berfungsi budaya. Fungsi inilah yang sering terabaikan atau kurang mendapat perhatian. Perintah Daerah lebih mengutamakan retribusi dari pada mengelola pasar tradisional. Gambaran yang muncul terhadap pasar tradisional jadi negatif seperti pasar tradisional dipandang sebagai daerah yang kotor, sumber kemacetan lalu lintas dan tempat berasalnya para pelaku kriminal.

Tidak jauh berbeda dengan Kabupaten dan Kota lainya di Indonesia, pasar tradisional di Kota Surakarta juga memunculkan berbagai permasalahan tersebut. Kondisi pasar tradisional di Kota Surakarta secara fisik umumnya buruk, berkembang tanpa rencana, beroperasi melimpah sampai keluar wilayah lapaknya. Hal ini berdampak pada kemacetan lalu lintas disekitarnya, ketidak nyamanan konsumen rawan kebakaran dan menjadi elemen buruk dari kota dan wilayahnya termasuk mendorong kekumuhan disekitarnya (Puslitbang Sosial, Ekonomi dan Lingkungan, 2011).

Kerawanan pasar tradisional terhadap kebakaran juga disampaikan oleh Dewan Pimpinan Pusat Ikatan Pedagang Pasar Indonesia (IKKAPI) menyampaikan data bahwa sepanjang tahun 2015 telah terjadi 283 kasus kebakaran pasar di seluruh Indonesia. Pasar Klewer juga termasuk yang mengalami kebakaran hebat pada tanggal 27 Desember 2014.

Kebakaran Pasar menghanguskan dan menghancurkan sebagian besar pasar. Total kios di Pasar Klewer mencapai 2.300, dari jumlah tersebut 1.532 kios terbakar. Selain pedagang permanen yang mempunyai kios, terdapat pula pedagang yang tidak mempunyai kios yang disebut penjual oprokan berjumlah 825 orang serta pedagang kakilima yang biasanya memadati jalan sekitar Pasar Klewer jumlahnya mencapai 900 orang (Dinas Pengelolaan Pasar Kota Surakarta, 2016).

Efek kebakaran pasar ini berdampak luas dan merubah situasi kota Surakarta yang ramai dengan transaksi batik menjadi sepi pengunjung. Musibah tersebut dapat mengarah kepada berkurangnya kegiatan wisata belanja. Termasuk dalam kegiatan di bidang pariwisata, hotel dan restoran. Dampak hancurnya Pasar Klewer juga akan menimpa para pengusaha tekstil di berbagai daerah yang memiliki hubungan dagang dengan para pedagang Pasar Klewer, seperti Pekalongan, Jakarta, Semarang, Jogjakarta, Surabaya bahkan hingga luar Jawa.

Kebakaran pasar Klewer tidak hanya berdampak ekonomi, tapi juga berdampak social dan budaya. Perlu kehati-hatian Pemerintah Daerah Kota Surakarta dalam menanganinya. Pemerintah Kota Surakarta juga harus menyadari tidak akan bisa memulihkan kondisi Pasar Klewer tanpa melibatkan berbagai pihak.

Kondisi Pasar Klewer pasca kebakaran sangat kritis, masyaratat pasar dalam kondisi terpuruk dan kehilangan harapan. Mereka kehilangan aset dan pendapatan dalam waktu yang relatif cukup lama, yaitu sampai dengan pasar dibangun kembali dan beroperasi secara normal (Johansson et al. 2010) mengemukakan bahwa peran dari negosiasi antara pihak-pihak yang terlibat dalam kebijakan publik akan sangat menentukan arah perubahan dari suatu kebijakan. Keterlibatan segenap elemen masyarakat diharapkan mampu mengelola kondisi kritis dan menyelesaikan persoalan yang dihadapi bersama.

Berbagai upaya harus dilakukan oleh Pemerintah Kota Surakarta untuk memulihkan kondisi pasar Klewer pasca kebakaran dengan melibatkan pemangku kepentingan. Kompleksitas permasalahan yang terjadi akibat pasca kebakaran, pemerintah kota Surakarta mengambil kebijakan kolaborasi.

Berbagai upaya yang dilakukan oleh pemerintah kalau belum membuahkan hasil, maka pendekatan collaborative governance sangatlah tepat dijadikan alternatif. Kolaborasi bisa dilakukan sebagai upaya pemecahan masalah yang mempunyai legitimasi kuat karena melibatkan berbagai kelompok kepentingan untuk secara aktif berpartisipasi dan mengambil keputusan bersama untuk disetujui bersama-sama (Sudarmo 2015).

Secara umum collaborative governance muncul secara adaptif dengan sadar serta disengaja. Collaborative governance diciptakan karena kondisi-kondisi antara lain kompleksitas dan saling ketergantungan antar 
institusi, konflik antar kelompok kepentingan yang bersifat laten dan sulit diredam. Juga merupakan upaya mencari terobosan untuk mendapatkan legitimasi politik (Chris Ansell and Alison Gash 2009). Sedangkan menurut (Van Buuren 2009) di dalam proses-proses tata kelola dengan mudahnya memunculkan banyak kontroversi dan konflik diperlukan tindakan kolektif.

Kolaborasi dewasa ini muncul sebagai isu strategis dalam paradigma governance yang sudah bergeser dari paradigma government. Dalam perspektif kerja sama antar stakeholder, kolaborasi merupakan konsep relasi antar organisasi, relasi antar pemerintahan, aliansi stratejik dan networks multi organisasi (Agranoff and McGuire 2004). Isu-isu lain seperti network, social capital, pertanggungjawaban birokrasi, globalisasi dan local governance.

Keterbatasan pemerintah dalam kolaborasi dapat terbantu oleh sektor lain, walaupun tidak dapat dipungkiri kemungkinan peran pemerintah terkadang lebih mendominasi karena berperan sebagai sektor utama (Sudarmo 2012, 37).

Permasalahan yang mau digali dalam penelitian ini adalah bagaimana pemerintah kota Surakata melaksanakan collaborative governance dari perspektif civil society. Tujuan penelitian menganalisis pelaksanaan collaborative governance dari perspektif civil society.

Teori yang digunakan dalam penelitian ini merupakan modifikasi dari teori (Emerson, K., Nabatchi, T., Balogh 2011), (Bourgon 2009), (Lacina 2011), (Barber, T., Lenihan, D., Milloy, J., Fox 2007), (Bovaird 2012), (Chris Ansell and Alison Gash 2007).

Governance disambut kehadirannya sebagai sebuah konsep dan pendekatan untuk mengelola karena ia menekankan fakta bahwa bukan hanya pemerintah, melainkan sektor publik yang berhubungan dengannya, bahkan dibimbing olehnya. Sektor tersebut adalah sektor privat dan civil society, yang menciptakan lingkungan tempat negaranegara menjadi sedikit banyak mencapai keberhasilan demokrasi dan ekonominya (Rosenbaum 2012). Hakikat dari governance adalah fokus pada mekanisme-mekanisme pengelolaan yang tidak terpaku pada recourse otoritas dan sanksi-sanksi pemerintah. Governance merupakan sebuah interaksi dari sebuah pengelolaan oleh banyak pihak dan masing-masing merupakan aktor atau pelaku yang sama-sama mempengaruhi (Stoker 1998).

Pemerintah, sektor swasta dan civil society secara bersama-sama akan bersinergi membentuk kerangka hukum dan institusi yang menjadi pedoman pelaksanaan fungsi administrasi publik pada khususnya dan masyarakat pada umumnya. Kolaborasi ketiga sektor tersebut menjadikan penyelenggaraan administrasi publik lebih berwarna, artinya beberapa faktor yang mempengaruhi keberhasilan dalam rangka mewujudkan kesejahteraan masyarakat dapat diakomodasi dan tidak semata-mata dimonopoli perannya oleh pemerintah.

Collaborative governance adalah sinergi yang dilakukan oleh Pemerintah Kota Surakarta dengan melibatkan pihak civil society dan pihak private dalam pengelolaan Pasar Klewer pasca kebakaran. Perspektif civil society meliputi aspek ketahanan budaya, benefit dan partisipasi. Ketahanan budaya merupakan kekuatan dan keteguhan untuk mempertahankan nilai yang sudah melembaga dalam kehidupan masyarakat pasar. Akses yang dibangun civil society terhadap Keraton dan Perbankan, membuka peluang usaha. Civil society berpartisipasi dalam bentuk keterlibatan mulai dari pengambilan keputusan sampai dengan beroperasinya pasar.

\section{METODE PENELITIAN}

Penelitian ini tergolong tipe penelitian deskriptif, yaitu penelitian yang bertujuan untuk menggambarkan dan mendeskripsikan objek dan fenomena yang diteliti. Termasuk di dalamnya bagaimana unsur-unsur yang ada dalam variabel penelitian itu berinteraksi satu sama lain dan ada pula produk yang berlangsung (Siagian, 2011). Jenis penelitian ini adalah deskriptif kualitatif, melalui penelitian ini peneliti ingin mengetahui faktorfaktor yang menyebabkan anak putus sekolah dan strategi pemerintah kelurahan dalam meningkatkan SDM anak putus sekolah di Kelurahan Belawan I Lingkungan XII Kampung Nelayan. 
Informan dalam penelitian memiliki peran yang sangat penting dalam pengambilan data dan informasi. Menurut (Afrizal, 2016) informan penelitian adalah orang yang memberikan informasi baik tentang dirinya ataupun orang lain atau suatu kejadian atau suatu hal kepada peneliti atau pewawancara mendalam. Informan tersebut terbagi 3 yakni informan kunci, informan utama dan informan tambahan. Yang menjadi informan kunci dalam penelitian ini adalah Lurah yaitu ibu Siti Maryam, S.Sos. Sementara itu, informan utama dalam penelitian ini adalah Kepala Lingkungan XII Kampung Nalayan yaitu ibu Sarawiyah. Adapun yang menjadi informan tambahan dalam penelitian ini adalah beberapa masyarakat yang bermukim di Kelurahan Belawan I Lingkungan XII Kampung Nelayan berjumlah 6 orang.

Selanjutnya Menurut (Sugiyono, 2015) teknik pengumpulan data merupakan langkah yang paling utama dalam penelitian, karena tujuan utama dari penelitian adalah mendapatkan data. Teknik pengumpulan data dapat dilakukan dengan observasi (pengamatan), interview (wawancara), dan dokumentasi. Kemudian metode analisis data, penelitian ini yakni pengumpulan data, reduksi data dan penyajian data (Huberman, 2012).

\section{HASIL DAN PEMBAHASAN}

Civil Society menurut (Anggara 2012) adalah wilayah kehidupan sosial terorganisir yang terbuka, sukarela, menghasilkan diri sendiri, mandiri (sekurang-kurangnya setengah mandiri), otonom dari negara, dan terikat oleh tatanan hukum atau seperangkat aturan bersama. Berbeda dari masyarakat pada umumnya, dalam hal melibatkan warga negara untuk bertindak secara kolektif dalam ruang publik guna mengekspresikan kepentingan, hasrat, preferensi, dan ide mereka untuk bertukar informasi, untuk mencapai tujuan-tujuan kolektif, untuk mengajukan tuntutan-tuntutan pada negara, untuk meningkatkan struktur dan fungsi negara, dan untuk memegang para pejabat negara agar bertanggung jawab. Civil societyadalah sebuah fenomena perantara yang berdiri di antara wilayah pribadi dan negara.
Menurut (Sranko, 2011) collaborative governance mengacu pada adanya institusiinstitusi yang mendorong interaksi diantara aktor-aktor organisasi pemerintah dan aktoraktor organisasi non-pemerintah dengan kedudukan setara tanpa adanya monopoli, tidak ada yang mendominasi dalam proses pengambilan keputusan atau proses kebijakan.

Kolaborasi mengandung pengertian kelompok kerja untuk bekerja sama untuk mencapai tujuan bersama, yang bekerja secara lintas batas dalam hubungan multi sektoral di mana hubungan tersebut pada nilai timbal balik (O'Leary 2007). Pemerintah Kota Surakarta dalam melakukan upaya kolaborasi dengan civil society, memberikan kewenangan tidak dalam bentuk tertulis untuk berperan dalam aspek ketahanan budaya, benefit, dan partisipasi.

Pasar tradisional menjadi salah satu pilihan prioritas yang diperhatikan pemerintah karena sejumlah alasan. Pertama, seperti yang menjadi visinya Kota Surakarta berkehendak untuk menjadi kota budaya. Kota budaya yang menjadi cita-cita bersama ini mensyaratkan penghormatan dan pelestarian nilai-nilai kebudayaan lokal yang pernah tumbuh. Faktor kesejarahan memegang peranan penting bagi Kota Solo yang sarat dengan hasil kebudayaan. Solo Future is Solo Past yang menjadi pemikiran bagi Pemerintah Kota Surakarta di dalam membangun kotanya.

Salah satu pasar tradisional yang menjadi andalan Kota Surakarta adalah Pasar Klewer, terletak persis di sebelah Barat Keraton Kasunan Surakarta Hadiningrat, terkenal sebagai pasar sandang utamanya kain dan pakaian batik, Pasar Klewer merupakan pasar yang hampir selalu disambangi oleh pengunjung Kota Solo. Di pasar ini, 2.810 pedagang, menggelar aneka rupa dagangan termasuk komoditi pendukung seperti aksesoris pakaian ataupun oleh-oleh.

Pertumbuhan Pasar Klewer sebagai pasar sandang utamanya batik, tidak terlepas dari dikenalnya industrialisasi kain batik dengan dikenalnya teknologi cap dan malam. Pada masa lalu, kain batik merupakan kain bermotif hanya boleh dikenakan oleh kaum bangsawan yang pembuatannya hanya bisa dilakukan dengan manual atau ditulis dengan tangan. Kain batik dipergunakan sebagai 
simbul dan ritual upacara adat masyarakat jawa.

Keberadaan Pasar Klewer ini ditopang oleh industri batik di kampung kauman yang berada di seputaran Masjid Agung serta Kampung Laweyan. Dua kampung ini saat ini dijadikan kampung wisata batik. Pasar Klewer memiliki dua buah bangunan yang salah satunya merupakan bangunan bertingkat di atas tanah bekas tanah swapraja. Pada awal pertumbuhanya, di Pasar Klewer juga terdapat pedangang sepeda dan burung namun kemudian dua jenis dagangan itu dipindahkan ke Alun-alun Selatan dan Widuran.

Bangunan fisik Pasar Klewer saat ini merupakan bangunan yang didirikan pada tahun 1971. Banyaknya pedagang yang berjualan sementara daya tampung pasar ini terbatas karena sejak ada perluasan di sisi timur pada tahun 1986 atau 25 tahun silan belum pernah dipugar lagi,membuat pasar ini lumayan sesak. Lorong sangat semput, namun hal itu justru mengasyikan karena ada suasana khas yang tidak dijumpai di tempat perbelanjaan lainya.

Pasar Klewer pada akhir tahun 2014 bagian sisi barat yang merupakan bangunan induk habis terbakar. Pemerintah Kota Surakarta Para pedagang terpaksa berjualan di pasar sementara yang di bangun di Alun-alun Utara Keraton Surakarta. Pembangunan kembali Pasar Klewer tengah dikerjakan dan diharapkan sudah dapat dipergunakan kembali.

Penataan dan pembenahan pasar tradisional dilakukan dengan berbagai pendekatan termasuk pendekatan kebudayaan. Dinas Pengelola Pasar membentuk sebuah satuan tugas yang dinamai Bergoda Rekso Harjo. Pasukan ini memiliki atribut tradisional yang bertugas untuk melakukan sosialisasi dan mengingatkan agar para pedagang mematuhi aturan. Bergoda Rekso Harjo selalu menjadi ujung tombak dalam kegiatan kebudayaan yang dilakukan para pedagang pasar tradisional.

Sebagai pusat perdagangan batik, Pasar Klewer menyediakan segala jenis kain batik, baik yang dipergunakan untuk pakaian seharihari maupun yang dipergunakan untuk ritual upacara pernikahan, kelahiran, dan momenmomen adat dan budaya masyarakat. Motif batik mempunyai filosofi melambangkan makna mendalam tentang kehidupan. Motif tersebut tidak dapat dijumpai secara lengkap di lain, akan tetapi di Pasar Klewer jenis-jenis tersebut dijamin ketersediaannya.

Daya tarik Pasar Klewer selain sebagai pusat batik yang kental dengan budaya dan nilai-nilai luhur Keraton, juga pada makanan khas yang brandnya melekat pada Pasar Klewer. Tengkleng Klewer yang berlokasi di sekitar Pasar Klewer merupakan makanan yang legendaris dan menjadi jujugan pejabat negara sampai Presiden, artis-artis terkenal dan publik figur. Ciri khas Tengkleng Klewer adalah cara penyajiannya yang menggunakan "pincukan" atau menggunakan daun pisang dari awal berdiri sampai sekarang. Rasanya yang khas, bumbunya yang meresap sampai ke tulang serta dagingnya yang empuk dan lezat. Makanan khas yang ada di Pasar Klewer adalah baksonya. Salah satu kedai yang paling banyak dicari oleh wisatawan adalah Bakso Klewer Prawiroredjo, kini dikelola oleh generasi ketiganya. Seporsinya terdiri bihun, tahu, pangsit goreng, babat, potongan daging sapi, serta bola daging halus tanpa serat. Satu mangkuknya juga ditambah sayuran sawi segar, kuah kaldu yang dimasak dengan sempurna. Rasa bakso tersebut membuat ngangeni para pengunjung.

Pasar Klewer menjadi ikon Kota Surakarta dan menjadi salah satu destinasi wisata. Posisi Pasar Klewer yang strategis menjadi bagian dari konsep catur gatra utama disimbolkan dengan Keraton, Alun-alun, Masjid dan Pasar. Keraton adalah simbol pemerintahan, Alun-alun sebagai simbol kerakyatan, masjid sebagai simbol religi dan pasar sebagai simbol penghidupan. Masyarakat yang datang ke Kota Solo untuk berwisata menjadikan Pasar Klewer sebagai paket lokasi yang dikunjungi.

Secara sosiologis dan kultural, makna filosofis sebuah pasar tradisional tidak hanya merupakan arena jual beli barang atau jasa, namun merupakan tempat pertemuan warga masyarakat untuk saling berinteraksi sosial, sarana bersilaturahmi, dan melakukan diskusi informal atas permasalahan hangat yang sedang terjadi di tengah-tengah masyarakat. Pemaknaan ini merefleksikan fungsi pasar tradisional yang lebih luas. Sebagian besar 
pedagang menganggap Pasar Klewer adalah rumah kedua bagi mereka. Masyarakat pasar dapat menjaga keseimbangan antara persingan bisnis dan kekerabatan yang kental. Nilai luhur budaya Jawa yang bersumber dari Keraton tetap dilestarikan secara turuntemurun, mereka memegang teguh prinsip kejujuran, kesantunan, dan nguwongke uwong (menghargai orang lain). Nilai-nilai tersebut yang diyakini memberikan berkah sehingga Pasar Klewer tetap dapat menjaga kejayaannya.

\section{Aspek Ketahanan Budaya}

Masyarakat Pasar Klewer sebelum terbakar sudah terbangun nilai kekerabatan yang tetap terpelihara dari generasi ke generasi. Pasar Klewer seperti pada umumnya sebuah pasar sarat akan kepentingan ekonomi, yang menjadikan iklim persaingan dalam kehidupan pasar. Keunikan Pasar Klewer adalah harmonisasi antara iklim persaingan dan suasana kekerabatan. Kekerabatan tetap terpelihara walupun berganti generasi karena kearifan lokal dan warisan nilai-nilai Keraton.

Masyarakat pasar menganut konsep budaya patron-klien, mereka memposisikan diri sebagai anak buah dan pemerintah sebagai bapak. Budaya yang dianut ini menempatkan masyarakat pasar pada posisi yang lemah, mereka tidak mempunyai bargaining (nilai tawar) yang kuat ketika berhadapan dengan pemerintah. Budaya patron-klien bertahan lama karena masyarakat pasar menyadari bahwa Pasar Klewer merupakan aset milik Pemerintah Kota Surakarta. Masyarakat pasar perlu diedukasi bahwa era pemerintahan modern, pemerintah menempatkan masyarakat sebagai pihak yang harus dilayani.

Hubungan patron-klien merupakan pertukaran hubungan antara kedua peran yang dapat dinyatakan sebagai kasus khusus dari ikatan yang melibatkan persahabatan instrumental di mana seorang individu dengan status sosio-ekonominya yang lebih tinggi menggunakan pengaruh dan sumber dayanya untuk menyediakan perlindungan, serta keuntungan-keuntungan bagi seseorang dengan status yang dianggapnyanya lebih rendah. Klien kemudian membalasnya dengan menawarkan dukungan umum dan bantuan termasuk jasa pribadi kepada patronnya (Scott 1977).
Berdasarkan hasil wawancara dengan Walikota Surakarta, FX. Hadi Rudyatmo, beliau mengatakan bahwa Pasar klewer sebagai pasar tradisional juga memiliki nilai yang tidak hanya bernilai ekonomi tapi juga sebagai sarana interaksi sosial. Pasar Klewer bagi sebagian pedagang merupakan rumah kedua bagi mereka. Interaksi sosial yang dibangun dalam waktu yang relatif lama oleh para pedagang melahirkan hubungan kekerabatan yang kental. Kekerabatan antar pedagang tidak hanya di pasar tapi jika ada pedagang yang punya hajat maka menjadi kebiasaan dilaksanakan tidak pada hari efektif pasar atau pada hari ramai pengunjung, dengan maksud agar sesama pedagang dapat menghadiri.

Pemerintah Kota dalam mendukung nilai-nilai kekerabatan yang berlaku di Pasar Klewer, menempatkan petugas berdasarkan kriteria yang dipilih diantara pegawai yang menguasai nilai-nilai lokal yang berlaku di pasar. Kekerabatan yang dibangun oleh petugas pasar (pegawai Pemerintah Kota) di pasar diwujudkan dengan kemampuan petugas untuk membaur dengan masyarakat pasar. Petugas dan masyarakat pasar membangun pola komunikasi dan interaksi layaknya sebuah keluarga.

Penataan pasar baru pasca kebakaran dengan sistem cluster menempatkan pedagang sesuai dengan jenis dagangan pada lantai yang berbeda. Pedagang tidak dapat secara bebas berbaur karena dibatasi oleh jarak dan regulasi, misalnya tidak memperbolehkan pedagang asongan berkeliling pasar. Nilai kekerabatan yang dibangun dari generasi ke genarasi memudar dan digantikan dengan teknologi komunikasi ( $\mathrm{Hp}$ ) yang mempunyai banyak keterbatasan.

Berdasarkan hasil wawancara dengan salah satu pedagang, Fatimah, mengatakan bahwa pedadagang Pasar Klewer pasca kebakaran tetap memegang teguh nilai kejujuran, keramah-tamahan, dan nguwongke uwong (menghargai sesama). Terpeliharanya nilai-nilai tersebut tidak lepas dari budaya Keraton yang tetap nguri-uri (memelihara) nilai luhur budaya Jawa. Hubungan timbal balik antara pedagang dan pihak Keraton menjadi penguat eksistensi pasar.

Pasar Klewer menjadi hal yang tidak terpisahkan bagi Keraton, ketika Keraton 
dibangun dirancang konsep empat pilar yang merupakan bagian penting dari kebutuhan manusia. Empat pilar tersebut terdiri dari Keraton sebagai pusat pemerintahan, Pasar Klewer sebagai pusat perekonomian, Masjid Agung sebagai pusat keagamaan, dan Alunalun sebagai pusat pagelaran budaya.

Masyarakat Pasar Klewer berkeyakinan dengan nguri-uri (memelihara) adat budaya Keraton dapat mendatangkan berkah sehinga dagangan laris dan pasar ramai pengunjung. Bagi pihak Keraton, Pasar Klewer merupakan pamor (semarak), jika pasar ramai pengunjung pamor Keraton naik, begitu pula sebaliknya jika pengunjung sepi pamor Keraton menjadi turun. Hubungan tersebut yang menjadi kunci keberhasilan himpunan pedagang mendapatkan ijin pasar darurat di lokasi Alunalun yang merupakan tanah milik Keraton.

Nilai-nilai kearifan lokal yang masih dipertahankan oleh pedagang Pasar Klewer sejalan dengan pendapat (Schement 1998) bahwa budaya lokal yang ditujukan untuk menata kehidupan dan dijadikan panutan dalam menjalani kehidupan. Budaya lokal yang kemudian dilembagakan menjadi sebuah kearifan lokal merupakan proses dan produk revitalisasi dan transformasi pengetahuan dan budaya, praktik-praktik adat (Levvit 2003). Kehidupan Pasar Klewer yang mengedepankan dan tetap melestarikan kearifan lokal, menjadikan salah satu keunggulan sehingga menjadikan daya tarik tersendiri.

\section{Aspek Benefit}

Lokasi pasar darurat tepat bersebelahan dengan pasar yang terbakar sehingga tidak mengurangi nilai strategis Pasar Klewer. Pasar darurat dengan bangunan semi permanen yang representative, dibangun dengan sumber biaya dari APBD Kota Surakarta, APBD Provinsi Jawa Tengah, sumbangan dari pihak swasta, dan menempati lokasi milik Keraton. Kolaborasi dalam membangun pasar darurat dapat mempercepat pemulihan kehidupan Pasar Klewer, masyarakat pasar kembali dapat melakukan usahanya walaupun di pasar darurat, dengan demikian perputaran roda perekonomian Pasar Klewer dapat berputar kembali dan berdampak pula pada perekonomian Kota Surakarta dan masyarakat sekitarnya yang terkait dengan operasional pasar.

Semangat masyarakat Pasar Klewer untuk bangkit menjadi poin tersendiri dalam mensukseskan kolaborasi. Semangat tersebut dilandasi oleh faktor kepentingan ekonomi dan faktor prestige. Faktor kepentingan ekonomi didorong oleh tuntutan pemenuhan kebutuhan keluarga yang harus dicukupi. Faktor prestige didorong oleh pandangan masyarakat luas bahwa Pasar Klewer merupakan simbol eksistensi pengusaha lokal di bidang perdagangan. Faktanya di Kota Surakarta pengusaha sukses di bidang perdagangan didominasi oleh etnis tertentu.

Pedagang Pasar Klewer dapat mempertahankan eksistensinya karena adanya spirit kekerabatan dan mempertahankan nilai luhur Keraton. Pedagang tidak mudah diintervensi oleh pedagang-pedagang besar dengan modal kuat yang mayoritas dari salah satu etnis yang mendominasi perekonomian di Kota Surakarta.

Masyarakat Pasar Klewer melalui perhimpunan pedagang dengan jaringan yang difasilitasi Pemerintah Kota Surakarta membuka akses ke pihak Perbankan. Akses tersebut dipergunakan sebagai sarana pendekatan agar swasta berkontribusi terhadap kesulitan yang dihadapi masyarakat pasar khususnya para pedagang. Pendekatan tersebut menghasilkan kebijakan khusus dari Perbankan berupa reschedule pembayaran pinjaman dan skema khusus pinjaman modal tanpa jaminan dan proses cepat cair bagi peminjam baru.

Berdasarkan hasil wawancara dengan Pengurus Himpunan Pedagang Pasar Klewer, Ibu Kadir, mengatakan bahwa Perhimpunan Pedagang juga membuka akses ke pihak media massa dan biro periklanan yang ada di Kota Surakarta untuk mendapatkan dukungan promosi dan publikasi. Promosi dan publikasi dilakukan dengan bekerja sama dengan media massa serta biro iklan (advertising agency). Promosi dan publikasi dalam bentuk iklan, baliho, spanduk membutuhkan biaya besar, akan tetapi dengan bekerja sama dengan pihak media massa yang peduli terhadap pasar tradisional khususnya Pasar Klewer pedagang melalui perhimpunan mendapatkan diskon atau harga khusus, bahkan iklan pada media 
massa digratiskan, baliho dan spanduk yang ditangani oleh biro iklan hanya dikenakan biaya produksi, sedangkan Pemerintah Kota Surakarta melalui Dinas Pendapatan dengan persetujuan Walikota membebaskan dari pajak reklame/iklan.

Dukungan berupa diskon biaya pemasangan iklan dan pembebasan pajak reklame oleh Pemerintah Kota Surakarta, sangat membantu bagi pedagang karena pasca kebakaran mereka tidak mempunyai dana untuk dialokasikan membiayai promosi dan publikasi.

\section{Aspek Partisipasi}

Menurut (Vigoda 2002) yang menghambat signifikansi tindakan dan partisipasi warga melalui tekanan yang berlebihan terhadap gagasan tentang daya respon. Kemajuan mengarah pada penguatan kemitraan antara government dan lembaga administrasi publik, warga dan para pelaku sosial lainnya seperti sektor swasta dan pihak ketiga. Interaksi alternatif dari gerakan antara government, civil society dan private dalam collaborative governance dirasa semakin realistis untuk beberapa tahun mendatang.

Berdasarkan hasil wawancara dengan Kepala Dinas Pengelolaan Pasar, Subagyo, bahwa pelibatan civil society (masyarakat Pasar Klewer) untuk menentukan tata letak lapak jualan dan penempatan pedagang sesuai dengan keadaan sebelum kebakaran. Pedagang memiliki kewenangan untuk menentukan mekanisme kegiatan perdagangan di Pasar Klewer meskipun pengadaan pasar dilakukan oleh pemerintah.

Masyarakat pasar tidak hanya mengandalkan pegelola pasar yang ditugaskan oleh Pemerintah Kota Surakarta, akan tetapi berperan aktif untuk memelihara kebersihan, keamanan, dan ketertiban. Masyarakat pasar secara mandiri melakukan pengadaan alat kebersihan yang dipergunakan untuk membersihkan lingkungan disekitar tempat berdagang masing-masing. Himpunan pedagang mengajukan bantuan ke pihak swasta untuk pemasangan CCTV (Closed Circuit Television) serta berpartisipasi dalam menjaga dan menegakkan ketertiban.

Berdasarkan hasil wawancara dengan Lurah Pasar Klewer, Edi Murdiarso, masyarakat pasar dan petugas perlu mempersiapkan diri mengantisipasi jika kebakaran terjadi lagi melalui pelatihan, simulasi, dan evakuasi. Para pedagang dan petugas pasar diharapkan sudah siap apabila terjadi kebakaran, termasuk pengunjung yang ada di dalam pasar bisa di evakuasi dan diselamatkan. Prinsip pelatihan menekankan tindakan pencegahan terjadinya kebakaran, jika terjadi kebakaran bagaimana cara mengatasinya, bagaimana cara menanganinya, bagaimana melaporkan ke Dinas Pemadam. Diperkenalkan pula perilaku dan teori api, serta penggunaan alat pemadam sederhana seperti APAR (alat pemadam api ringan) hingga hidran.

Penegakan ketertiban yang dilakukan dengan memasang board peringatan dilarang merokok dan dilarang parkir pada titik-titik tertentu. Masyarakat pasar dan pemerintah sepakat yang berwenang untuk menegur bagi pelanggar aturan tersebut tidak hanya petugas pemerintah, akan tetapi juga memberikan kewenangan kepada perhimpunan pedagang. (Dwiyanto 2004) dengan adanya partisipasi akan mendatangkan keuntungan legitimasi yang lebih besar, serta memberikan citra positif sebagai suatu masyarakat yang demokratis. (Arnstein 1969) menyebutkan bahwa partisipasi pada tingkatan kekuatan masyarakat dapat dimanfaatkan oleh pemerintah sebagai upaya memberdayakan masyarakat serta mampu membantu pemerintah dalam menjalankan tugas mereka.

Pemerintah seharusnya tidak melimpahkan kewenangan di bidang keamanan dan ketertiban kepada perhimpunan pedagang pasar. Kewenangan tersebut seharusnya menjadi tanggung jawab sepenuhnya pemerintah dengan menempatkan petugas secara permanen. Petugas Dinas Perhubungan ditempatkan terkait dengan ketertiban lalu lintas disekitar pasar. Petugas Satuan Polisi Pamong Pradja (Satpol PP) ditugaskan untuk melakukan penindakan terhadap pelanggaran ketertiban dan keamanan. Pedagang merasa segan jika menjumpai pelanggaran sedangkan tidak ada petugas maka mereka tidak berani mengambil tindakan, karena terkendala budaya ewuhpekewuh (menjaga perasaan).

Himpunan pedagang mempunyai peran penting dalam meredam konflik. Pada saat 
penempatan pasar baru timbul gejolak, beberapa pedagang tidak terima dengan berkurangnya space atau luas kios, bergeser ke lokasi yang kurang strategis, dan berkurangnya jumlah kios. Berkurangnya luas dan bergesernya lokasi kios disebabkan banyaknya tiang atau balok beton akibat tuntutan standart konstruksi. Berkurangnya jumlah kios merupakan kebijakan pemerintah untuk membatasi dominasi kepemilikan dan untuk pemerataan.

Seharusnya pemerintah melakukan sosialisasi intensif kepada pedagang terkait situasi dan kebijakan tesebut. Sosialisasi intensif dimaksudkan untuk memberikan pemahaman agar perubahan-perubahan dapat diterima masyarakat pasar. Himpunan pedagang melakukan pendekatan-pendekatan kekeluargaan untuk meredam gejolak dengan mengajak anggotanya untuk nerimo ing pandum (menerima dalam keadaan apapun).

Himpunan pedagang juga memberikan pemahaman jika pasar sepenuhnya adalah aset milik pemerintah. Pemerintah sudah punya itikad baik dengan segala daya upaya untuk memulihkan dan membangun kembali Pasar Klewer dengan kelengkapan fasilitas yang sangat layak. Pendekatan yang dilakukan himpunan pedagang efektif, dengan berjalannya waktu pedagang yang bergejolak dapat diredam. Pemerintah sangat terbantu oleh himpunan pedagang, sehingga energi dan waktu pemerintah dapat dipergunakan untuk menangani persoalan lain.

\section{SIMPULAN}

Masyarakat pasar menjadi bagian dari kolaborasi yang diinisiasi dan diprakarsai oleh Pemerintah Kota Surakarta melalui perhimpunan pedagang. Kontribusi perhimpunan pedagang dalam kolaborasi yaitu meredam konflik serta mengkondisikan anggotanya agar tercipta suasana yang harmonis dan kondusif. Kontribusi tersebut dalam rangka mendukung efektivitas penanganan pasar pasca kebakaran sampai dengan beroperasinya pasar secara normal, sehingga masyarakat pasar dapat melakukan aktivitas usahanya dengan tenang dan nyaman. Kontribusi tersebut menciptakan sebuah kehidupan pasar yang adem ayem (tenang dan tenteram) dan kondusif.
Masyarakat pasar dalam kolaborasi tidak hanya mengandalkan dan bergantung pada pihak pemerintah dan pihak swasta. Masyarakat pasar juga berpartisipasi secara aktif terkait kelancaran operasional Pasar Klewer dengan ikut menjaga dan memelihara kebersihan, keamanan, ketertiban, dan menyiapkan diri atau mengantisipasi jika terjadi kebakaran pasar terulang kembali.

Civil society sebagai perspektif dalam collaborative governance yang mencakup aspek ketahanan budaya, benefit dan partisipasi dapat mempertahankan nilai luhur budaya lokal warisan Keraton, semangat untuk bangkit termotivasi tuntutan pemenuhan kebutuhan keluarga dan sebagai simbol pengusaha lokal, dan berpartisipasi dalam kelancaran kegiatan atau operasional pasar menjadikan kolaborasi pengelolaan Pasar Klewer pasca kebakaran lebih efektif.

\section{DAFTAR PUSTAKA}

Agranoff, Robert, and Michael McGuire. 2004. Collaborative Public Management: New Strategies for Local Governments. Collaborative Public Management: New Strategies for Local Governments. Vol. 67. Washington: Georgetown University Press. https://doi.org/10.5860/choice.41-1215.

Anggara, Sahya. 2012. Ilmu Administrasi Negara. Bandung: Pustaka Setia.

Arnstein, Sherry R. 1969. "A Ladder Of Citizen Participation. Journal of the American Institute of Planners." Journal of The American Institute Of Planners 35 (4):21624.

https://doi.org/10.1080/019443669089772 25.

Barber, T., Lenihan, D., Milloy, J., Fox, G. 2007. "Progressive Governance for Canadians: What You Need to Know. Ottawa: Public Policy Forum."

Bourgon, Jocelyne. 2009. "New Governance and Public Administration: Towards a Dynamic Synthesis. Centre for International Governance Innovation, Canada School of Public Service Canberra, Australia."

Bovaird, T. 2012. "Public Governance: Balancing Stakeholder Power In A Network Society. SAGE Publications (London, Thousand Oaks, CA and New Delhi)" 71: 217-27.

Buuren, Arwin van. 2009. "Knowledge for Governance, Governance of Knowledge: Inclusive Knowledge Management in Collaborative Governance Processes." International Public Management Journal 12 
(2):208-235.

https://doi.org/10.1080/109674909028685

23.

Chris Ansell, and Alison Gash. 2007. "Collaborative Governance in Theory and Practice." Journal of Public Administration Research and Theory 18 (4): 543-71.

Chris Ansell and Alison Gash. 2009. Pragmatism and Collaborative Governance. Berkeley: Departement of Political Sience, Unibersity of California.

Creswell, John W. 2012. "Penelitian Kualitatif Dan Desain Riset (Memilih Diantara Lima Pendekatan)." In Penelitian Kualitatif, Indonesia. Yogyakarta: Pustaka Pelajar.

Dwiyanto, A. 2004. "Reorientasi Ilmu Administrasi Publik: Dari Government Ke Governance. Pidato Pengukuhan Jabatan Guru Besar Pada FISIPOL UGM, Yogyakarta."

Emerson, K., Nabatchi, T., Balogh, S. 2011. "An Integrative Framework for Collaborative Governance." Journal of Public Administration Research and Theory 22: 129.

Johansson, Karl Erik V., Ole Elgström, Ngolia Kimanzu, Jan Erik Nylund, and Reidar Persson. 2010. Trends in Development Aid, Negotiation Processes and NGO Policy Change. Voluntas 21 (3): 371-92. https://doi.org/10.1007/s11266-010-9131$\mathrm{y}$.

Lacina, Karel. 2011. "Remarks to the Development of Public Administration from the Concept of Government 'to the Concept of Governance. ACTAV-SFS, 2/2011" 5: 126-45.

Levvit, Kathryn M. Anderson. 2003. Local Meaning Global Schooling. New York: Palgrave MacMillan.

Miles, B Mathew., Huberman, A Michael and Saldana, J. 2014. Qualitative Data Analysis. Third. Copyright (C) 2014 SAGE Publications, Inc.

Moleong, Lexi J. 2014. Metodologi Penelitian Kualitatif. Jakarta: Remaja Rosdakarya.

O'Leary, R and Bingham L.B. 2007. "Conclusion : Conflictand Collaboration and Networks." International Public Management Journal 10: 103-9.

Puslitbang Sosial, Ekonomi dan Lingkungan. 2011. Kajian Modernisasi Pengelolaan Pasar Tradisional Berbasis Modal Sosial. Departemen Pekerjaan Umum.

Rosenbaum, Allan. 2012. The Post-Governance Era in International. Public Administration: Returning to the Basics. Pennsylvania: TIMES International Supplement.
Schement, J. 1998. Thourough American: Minorities and the New Media in Curran. James \& Michael.

Scott, James C. 1977. Patron Client, Politics and Political Change in South East Asia. Followers and Factions a Reader in Political Clientalism. Berkeley: University of California Press.

Sobur, Alex. 2013. Filsafat Komunikasi. Bandung: PT. Remaja Rosdakarya.

Sranko, Geroge, R. 2011. “Collaborative Governance and Strategic Approuch to Fasilitating Change: Lesson Learned Form Fores Agreement In South East Queens Land And The Great Bear Rain Forest (P)." Interface: A Joaurnal For And About Social Movement 3.

Stoker, Gerry. 1998. "Governance as Theory: Five Propositions." International Social Science Journal $50 \quad$ (155): 17-28. https://doi.org/10.1111/1468-2451.00106.

Sudarmo. 2012. Isu-Isu Administrasi Publik Dalam Perspektif Governance. Solo: Smart Media.

-_—. 2015. Menuju Model Resolusi Konflik Berbasis Governance. Solo: Penerbitan \& Percetakan UNS.

Vigoda, Eran. 2002. "From Responsiveness to Collaboration: Governance, Citizens, and the Next Generation of Public Administration." Public Administration Review 62: 527-40. 